\title{
The Use of Code Switching in English Teaching
}

Eko

Universitas Perjuangan Tasikmalaya

ekokuciki@gmail.com

\begin{abstract}
This research is to describe code switching that teacher used in teaching process. The researcher wants to analysis the type and the function of using code switching by teacher because English is not compulsory subject in elementary school and English is still unfamiliar for Indonesian students. The subject was English teacher who teaches in seventh grade at SMPN 1 Parungponteng, Tasikmalaya. Based on the research, the teacher practiced code switching in order to help the students in delivering materials. In the process of code switching, the teacher practiced Bahasa Indonesia, Sundanese and English. The aims of this research were to classify the types of code switching and functions of code switching. It was descriptive qualitative research designs of which instrument are both observation and interview. The findings from the data analysis indicated that the types of code switching were found in three types: inter-sentential switching, intra-sentential switching, tag switching. The functions of code switching used by the teacher were found three functions: message reiteration, message qualification and interjection. Furthermore, the type reason of using code switching by teacher based on interview was repetition used for clarification because the teacher wants students understand what teacher has explained.
\end{abstract}

Keywords: code switching, sociolinguistics, bilingualism, English as a foreign language, EFL teaching.

\section{INTRODUCTION}

Code switching is one of phenomenon in teaching, especially for bilingualism or people who speak more than one language. in education, code switching is the option for teacher to explain something clearly when the teacher teaches foreign language. Furthermore, Indonesia is one of the countries that has many languages. Indonesian's teachers always use code switching to get better understanding when they have English class because they always switch English to Bahasa to convey what they have explained to students. in addition, English is foreign languages in Indonesia. English has been taught in every schools in Indonesia. Young learners have been prepared for the globalization era. In the globalization era, people should master English as an international language. This brings good impact for Indonesian people. Furthermore, in Indonesia English is taught at school. The aim of teaching English at school is to develop students' language skill. English has four major skills that should be mastered by students, they are speaking, reading, writing, and listening. English is challenging and requiring highly complex skills which go beyond the understanding of grammatical and semantic rules. 


\section{Journal of Applied Linguistics \\ 1(1), November 2019}

This research tries to analyze the phenomenon of code switching, during classroom interaction in English class. The reason why researcher chooses this topic, it is because the researcher is interested in finding the code switching that is used by English teacher in classroom. By conducting this research, it is hoped that the research will become a consideration for the teacher in deciding what language should be used in the classroom. The researcher will focus on the analysis of the use of code switching and the type of code switching that teacher uses in teaching process. Based on this reason the researcher is interested in the research with the title "The Use of Teacher's Code Switching in English Teaching".

\section{Code Switching in Teaching English}

Code switching is the phenomenon of alternating between two or more languages during spoken conversation (Ibrahim et al, 2013, pp. 139). Appel and Musyken (in Lee, H, 2010, pp. 5) suggest that code switching can be categorised as intrasentential. Intrasentential is a switch of languages which occurs in the middle of a sentence. This type of switching is often called 'code mixing'. It means that codeswitching is an activity to express ideas, events, feelings or thinking to other through code-switching by using another language. In a more recent publication, Unanumo (in Lee, H, 2010, pp. 5) regards code switching as the use of more than one language in a conversation. It is a tool to speak with two languages or more. By code switching we can explain something about fact and ideas too. Wardhaugh (in El-Saghir, K, 2010, pp. 1) says code is defined as the particular dialect or language one chooses to use on any given occasion and the communication system used between two or more parties. $\mathrm{He}$ asserts, "Most speakers command several varieties of any language they speak, and bilingualism, even multilingualism, is the norm for many people throughout the world rather than unilingualism”.

Based on the statement above, it can be concluded that code switching is one of the tools to express something such as ideas, events, feeling, and facts through in speech with more than one spoken language. Poplack (2004) also proposed types of code switching. The classification of code switching by Poplack is based on scope of switch. Poplack identified the following types: tag-switching, inter-sentential and intra-sentential.

\section{Inter-sentential switching}

The inter-sentential code switching is switching at the sentence level. intersentential code switching occurs when the speaker, after he / she has completed a sentence in one language, switches to another language in the next sentence, or occurs at sentence levels, where each clause 


\section{Journal of Applied Linguistics \\ 1(1), November 2019}

or sentence is in one language or the other as illustrated in the following examples demonstrating code switching between English and Indonesian. Nasution (2018, pp. 15) explained further about the example of inter-sentential code switching:

"You have the task for the next meeting.

Kamu harus membuat dialog pendek".

From example above it is intersentential switching because the speaker has completed a sentence in English "you have the task for the next meeting", and then speaker switches to Indonesian "kamu harus membuat dialog pendek" in the next sentence. The other example:

"Jangan kemana-mana sini aja! Do you understand?

From example above, it is included inter-sentential switching because the speaker has completed a sentence in Indonesian "Jangan kemana-mana sini aja" then speaker switch to English "do you understand" in the next sentence. So, intersentential switching happens when the speaker after has completed a sentence in one language switches to another language in the next sentence.

\section{Tag switching}

Tag switching in which tags in one language are inserted into an utterance otherwise in another. The speaker starts the sentence but attaches a tag-like switch (in English) at the end of the sentence to show emphasis or to symbolize that he/she is soliciting the opinion of the addressee. A tag code-switching happens when a speaker inserts short expressions (tag) from different language at the end of his/her utterances, e.g. "you know”, "I mean”, from one language into a clause or sentence in a different language. Since tags are subject to minimal syntactic restrictions, they may be easily inserted at a number of points in a monolingual utterance without violating syntactic rules. Nasution (2018, pp. 17) explained further about the example of tag switching:

"It's okay, no problem, ya nggak?"

It is a code switching because the utterance shows that the speaker switches from English "It's okay, no problem" to Indonesian "ya nggak?". This code switching which is existed in the last sentences is an insertion of a tag from one language into an utterance which is entirely in one another language. So, these utterances can be classified into extra sentential or tag switching.

\section{Intra-sentential switching}

Intra-sentential switching possibly the most complex type among the tree. In Intrasentential switching, code switching occurs two code within a clause. It means that the speaker inserted phrases, clauses from another language within the same sentence. It means that the speakers switch from one language to another within the same 


\section{Journal of Applied Linguistics \\ 1(1), November 2019}

sentence. In which switches occur within a clause or sentence boundary. Nasution (2018: 15) explained further about the example of intra -sentential code switching:

"Can you please tell me kalimat apa ini?"

"I'll give you a gift kalau kalian bisa jawab"

It is called code switching included intra-sentential switching. Because the utterance shows that the speaker switches from English into Indonesian in the single sentence or utterance.

"Selain di post office itu kita ngapain sii?"

From example above called code switching included intra-sentential switching. The utterance shows that the speaker inserted phrase of second language in first language in a sentence.

In the previous research written by Ibrahim et al (2013, pp. 141) about code switching, he found reason why the teachers use code switching that has six functions. Here are six functions proposed by Ibrahim based on Gumperz: (1) Message reiteration; to reiterate or repeat a message in another code in order to clarify, emphasize, and promote understanding. (2) Message qualification; to qualify a previously mentioned statement. In this situation the speaker believes that switching helps better understanding of the message. (3) Interjection or sentence filler; code- switching is used for better expression, clarification or better understanding. One of the subjects of this study frequently inserted Malay interjections into her utterances. (4) Personalization versus objectivization; code-switching was used to indicate the difference between fact and opinion. Codeswitching here is concerned more with the degree of speaker's involvement in, or distance from, a message, whether a statement reflects a personal opinion or knowledge, and whether it refers to specific instances or to a generally known fact. (5) Quotation; when functioning as quotation, code-switching contains direct quotations or reported speech. (6) Specific feature of Islamic English; Islamic English is the English language modified to enable Islamic proper nouns and meanings to be carried out without distortion, and to serve the linguistic needs of Muslims users of the English language.

Code switching is effective to assist communication in the class, especially to deliver the material. Sert (in Amorim, 2012:178) believes that in ELT classrooms, code switching comes into use either in the teachers' or the students' discourse. So, from that statement students should understand what teachers mean and then, it is conditionally to use code switching. Basically, communication is the first thing that is very important between students and teachers to support learning process. 


\section{Journal of Applied Linguistics \\ 1(1), November 2019}

Teachers and students should have good connection to engage each other.

Code switching has grammatical perspective. Grammatical approach focuses on the structural aspects of code switching, the aim of grammatical approach in code switching is to determine syntactic and morphological characteristics of code switching's construction (Van Dulm in Nur, N and Fitriyani, 2016, pp.85). Metila (in Bhatti, 2018, pp. 94) explains that the pedagogical and communicative functions of classroom code switching justify, it is used in teaching and learning contexts. Code switching has a variety of purposes in various forms; content delivery, managing discipline, humor and turn the mood. Ibrahim et al (2013) establishes the view that code switching is a part of a conversational strategy that can be used by bilingual speakers effectively to share social meanings that are influenced by social variables and morph syntactic structures of one or more languages. An analysis done by Ibrahim et al (2013) also shows that the teachers had a positive attitude towards code-switching, and despite the claim that they did not codeswitch, they actually did it in pedagogical purposes.

There are reasons for bilingual or multilingual person to switch or mix their languages. Proposed by Nur and Fitriani, those are: a). Talking about a particular topic. b). Quoting somebody else. c). Being emphatic about something (express solidarity). d). Interjection (inserting sentence fillers or sentence connectors). e). Repetition used for clarification. f). Because of real lexical need.

The phenomenon of code switching is to assist what students need while in teaching process, because teachers have the obligation to make them understand what teachers deliver during the teaching process, so there is no reason to let them wonder about it. In addition, code switching can help to answer the problem with this current situation between teachers and students.

\section{RESEARCH METHODOLOGY}

\section{Research design}

In this research, the researcher used qualitative research with grounded theory design. The qualitative research was used for developing the concept of sensitivity to the problems face. (Creswell, 2012, pp. 18) states in qualitative research typically you gather a text database, so the data analysis of text consists of dividing it into groups of sentences, called text segments, and determining the meaning of each group of sentences. The researcher conducted this research at SMPN 1 Parungponteng, Tasikmalaya.

The observation and interview were conducted at SMPN 1 Parungponteng in $27^{\text {th }}$ July $2019-3^{\text {rd }}$ October 2019 . The 
teacher was observed and asked about code switching in English teaching. The researcher did the observation and interview once.

This research deals with the purpose of knowing the type and the function of code switching in using by teacher. In analyzing, the researcher used Poplack's theory to explore the type of code switching and Gumperz's theory to identify the function of code switching.

\section{FINDING AND DISCUSSION}

This section began with the presenting of the findings found by the writer after conducting the research methods. The result of observation session was done by using voice recording, and the interviews with the teacher has already found by the writer.

The teacher who teach basic speaking, teach basic speaking of first semester in seventh grade A class academic year of 2019/2020. he tried to talk in English when explaining the lesson. However, because some of the students' speaking comprehension level is beginner to basic, he often switches the codes in order to clear his explanation.

According to the research conducted to the seventh grade of SMPN 1 Parungponteng, the researcher' purpose was to find out the type and the function of code switching in using by teacher. The researcher carried out observation in one meeting using voice recording in order to help finding out the types, the functions of code switching practised by the teacher. The observation was started on $27^{\text {th }}$ July $2019-3^{\text {rd }}$ October 2019. The data from the observation, a voice recording firstly was transcribed into the written transcript. The observation consisted of two main points to be found. There were the types of code switching and functions of code switching in the process of code switching by the teacher.

Table 1. Type of Code Switching used by English teacher

\begin{tabular}{lll}
\hline No & Type of Code Switching & Data \\
1 & Inter-Sentential Code Switching & 30 \\
2 & Tag Switching & 2 \\
3 & Intra-Sentential Code Switching & 15 \\
Total & 47 \\
\hline
\end{tabular}

The table above showed the types of code switching used by the teacher in the classroom. There are three types of code switching. They are inter-sentential switching, tag switching, and intra- sentential switching. Based on the findings, intra-sentential switching was the most common data which occurred in teacher's utterances with 15 data. This type is occurred two code within a clause. It means 


\section{Journal of Applied Linguistics \\ 1(1), November 2019}

that the teacher inserted phrases, clauses from another language within the same sentences. Then the second common type which occurred in teacher utterance was inter-sentential switching with 30 data. Inter-sentential switching occurs at a sentence boundary and this type mostly used for clarify or even to translating the teacher's utterances. And the least common type occurred in teacher utterance is tag switching with only 2 data. In this type the teacher used the type of tags switching was for emphasizing the sentence to the students. The table below is the functions of code switching used in the classroom.

Table 2. Function of Code Switching used by English teacher

\begin{tabular}{lll}
\hline No & Function of Code Switching & Data \\
1 & Message Reiteration & 31 \\
2 & Message Qualification & 14 \\
3 & Interjection & 2 \\
Total & & 47 \\
\hline
\end{tabular}

The table above showed the functions of code switching used by the teacher in the classroom. There are three function of code switching. They are message reiteration, message qualification and interjection. Based on the findings, the most common function which occur in teacher utterance is message reiteration with 31 data. Reiteration occurs mostly for clarify or to translating the teacher's previous utterances. The second most common function which occur in teacher utterance is message qualification with 14 data. The function of message qualification occurs when the teacher explained the material, and then gave further explanation in the next utterance. The third common function which occur in teacher utterance is interjection with 2 data. The function of interjection is used by teacher for better expression, clarification or better understanding in teaching process.

Based on the result of interviews the writer found that the teacher used code switching, it because of the students didn't understand about the English very well. So, the teacher switched his utterance in Bahasa after used English to make the students not confused or more understand when the teacher explained the lesson. The teacher used code switching in the teaching process because he wanted to make his utterance clearer when giving explanation so the students could understand faster, and then he also used code switching in the class in 
order to expressing his emotion or feeling to the students.

\section{CONCLUSION}

Dealing with the objective of this study, which is to identify the types and functions of code switching used by English teacher of the seventh grade students of SMPN 1 Parungponteng, there are three functions of code switching performed by the teacher, there three types of code switching performed by the teacher and there is one type of reason of code switching used by teacher.

\section{REFERENCES}

Arif, N. (2015). Removing English as Compulsory Subject from Primary Schools on the 2013 Curriculum Based on Teachers' Opinion. International Journal of Scientific and Research Publications, 5, 1-5.

Amorim, R. (2012). Code Switching In Student-Student Interaction; Functions And Reasons. 7, 177-195.

Bhatti, A., Shamsudin, S \& Said, S. (2018). Code-Switching: A Useful Foreign Language Teaching Tool in EFL Classrooms, 11 (6), 93-101.

Creswell, J, W. (2012). Educational Research: Planning, Conducting, and Evaluating Quantitative and Qualitative Research (4th ed). Boston: Pearson.
El-Saghir, K. (2010). Code-switching in Sociolinguistic Studies: Review and Analysis

Ibrahim, E., Shah, M \& Armia, N. (2013). Code-Switching in English as a Foreign Language Classroom: Teachers' Attitudes, English Language Teaching, 6 (7), 135-150.

Lee, H. (2010). Code Switching in the Teaching of English as a Second Language to Secondary School Students, Malaysian Journal of ELT Research, 6, 1-45.

Nasution, R, A. (2018). An Analysis of Code Switching Between English and Indonesia Language in Teaching Process of Speech on The English Department Students at The State Islamic University North Sumatera.

Nur \& Fitriyani. (2016). A Descriptive Analysis of English Indonesian Code Switching

Spoken by The Teacher in The First Grade of MTSN Model Makassar, 2 (1), 8295.

Poplack, S. (2004). An International Handbook of the Science of Language (2nd ed.). Berlin: Walter de Gyurter.

Wardaugh, R. (2006). An Introduction to Sociolinguistics. USA: Blackwell Publishing 